Original Research Paper

\title{
Small Innovative Enterprises of Universities
}

\author{
${ }^{1}$ Franz Edmundovich Sheregi and ${ }^{2}$ Alexey Valentinovich Ridiger \\ ${ }^{I}$ National Research Nuclear University (MEPhI), Center for Sociological Research (Sociocenter), Moscow, Russia \\ ${ }^{2}$ State Center Interphysica, Center for Sociological Research, Moscow, Russia
}

\author{
Article history \\ Received: 25-11-2015 \\ Revised: $12-03-2016$ \\ Accepted: 17-03-2016 \\ Corresponding Author: \\ Franz Edmundovich Sheregi \\ National Research Nuclear \\ University, Center for \\ Sociological Research \\ (Sociocenter), Moscow, Russia \\ Email: f-sheregi@inbox-ru
}

\begin{abstract}
The article analyzes the formation and operation of small innovative enterprises, established by Russian universities in the context of the technology platforms program, implemented in Russia and based on the experience of the developed countries. Facilitating the commercialization of university research activities by providing them with the right to set up small innovative businesses is a new phenomenon for Russia. This state program has been implemented since 2010 with legal and financial support from the government, the goal being the cooperation between universities, academic and industrial research institutions with industry. Established by universities, small enterprises are to serve as a link between research carried out at universities and manufacturers of innovative products; besides, the university innovative enterprises are to shift scientific products into innovative production. Taking the statistics of the Ministry of Education and Science of the Russian Federation and the experts' analysis as the basis for the research, the authors consider the challenges of setting up a university innovative enterprise, their non-uniform geographic distribution, excessive dependence on the state budget, insufficient involvement in the competitive market environment, serious bureaucratic and financial obstacles to their productive functioning. A large-scale study, carried out by the authors, shows that, in general, from 2011 to 2015 the performance of university innovative enterprises did not become profitable and what's more, a third of them had to declare bankruptcy. The article considers the reasons for the failure of university innovative enterprises to meet the expectations entrusted by their founders, as well as it considers their development potential.
\end{abstract}

Keywords: University Innovative Enterprise, Innovation, Scientific Cooperation, Technology Transfer, Commercialization of Science, Economic Efficiency

\section{Introduction}

In the early $1990 \mathrm{~s}$, there was a significant change in the composition of the Russian scientific organizations. There was a dramatic increase in the number of small research organizations that worked for industrial companies, their functions in most cases being illegal cash-out transaction and embezzlement by the customer and contractor, less frequently-receiving foreign grants. In 1990 those research organizations accounted for 38\% of the total number of scientific organizations in Russia and in 2003-67.3\% (Lapusta and Starostin, 1998; Sheregi et al., 2012). New research organizations were created in the 1990s, both as hiving off existing research organizations and as newly formed legal entities. They emerged in abundance at many organizations in the Russian Academy of Sciences, as well as at industrial research organizations and got legal right to freely manage their finances, whereas at that time many manufacturers did not have the same right and could manage their money only in non-cash form.

During the period of acute crisis, due to the absence of demand, increase in the number of small research organizations was accompanied by a decrease in the number of organizations previously working on transfer of new technologies into industry: From 1990 to 2005 Russian industrial enterprises saw a decrease in the number of engineering companies up to 8.7 times, design organizations-4.1 times and 1.8 times-fewer scientific and engineering organizations (SBR, 2005). The decrease in research and development organizations was also registered in the $2000 \mathrm{~s}$ : In 2004 their number amounted to 21.000 , in 2011 it was 13.100 . Over the same period the share of research organizations among small 
businesses fell from 2.2 to $1 \%$, while the share of small business investment in fixed assets went down from 0.8 to $0.4 \%$ (Zinov and Tsyganov, 2009; Sheregi and Klyucharev, 2013).

In the late $2000 \mathrm{~s}$ to promote applied research that would involve scientific and human resources of universities and research organizations as well as experts, engineering and commercial experience of producers, the Government of Russia facilitated the creation of a network of small innovative businesses, established by universities. Those small innovative enterprises were designed to support setting up the applied research, scientific products of which could be transferred to production within a short time, as it was stated in the law "On Science and State Scientific and Technical Policy" (RFL 127-FZ, 1996). The Register of Business Entities of Universities, approved in 2011, aimed at improving interaction between universities and small innovative enterprises (RFG Decree 146, 2011), as well as the Notification Register of Business Entities (small enterprises), created by public research institutions and universities (MES Order 1404, 2011). This task was solved successfully over 2009-2014 regarding the organizational aspect. However, a large study, carried out by the authors, shows that from 2011 to 2015 the overall performance of university innovative enterprises did not become economically efficient. What's more, a third of them had to declare bankruptcy. The article analyzes the reasons university innovative enterprises failed to meet their founders' expectations and also examines the prospects for their development.

\section{Literature Review}

The issues relating to university innovative enterprises attracted the attention of Russian scientists in the early 1990s, along with the passage of the "Law on Cooperatives" in the Soviet Union (RFL 41-FZ, 1996), which promoted not only wide-scale small business, but also initiated extensive market relations in the country. Analysis of the formation and functioning of small enterprises in the economic conditions, new for the USSR, was carried out under supervision of F. Sheregi on the basis of the All-Union monitoring, conducted a month after the adoption of the "Law on Cooperatives" and for the second time-the next year (Osipov et al., 2014). It was the first study of successes and failures of the Russian market, sources of accumulation of advance capital, the rate of sole proprietorship and cooperatives emergence in Russian regions.

In the early 2000 s, researchers mainly focused on the study of interaction of small innovative enterprises at the early stages of their development and elements of innovative infrastructure in the regions, operation of the newly formed research and consulting small enterprises, their relations with large traditional research organizations, the ways they established commercial contacts with the industry. In the first three years of public initiative aimed at supporting innovative small enterprises at universities, a number of researchers prepared a critical analysis of the state support and the prospects for small business innovation, drawing on the materials of the expert surveys (Zubova et al., 2013; Arkhipov, 2010; Grasmick and Mezenin, 2013; Bryalina, 2014), the potential interaction between macroeconomics companies and innovative small businesses (Chepurenko, 2009; Alexandrin, 2011; Tarasenko, 2011), management initiatives of small innovative business working in collaboration with universities (Avilova and Khvorova, 2011; Basareva, 2014), the search for reliable indicators to assess economic efficiency of small businesses with mixed, public-private financing (Kantserov and Gediev, 2012; Chuka and Panina, 2014).

Sgroi et al. (2014) reveal the peculiarities of development of small businesses in their studies. A number of their scientific results can be taken into account in the Russian practice of increasing small business efficiency.

Scientific papers, devoted to the issues of small innovative businesses at universities and published during 2010-2014, analyze structural elements and operation of small businesses (Tarasenko, 2011; Fiyaksel and Butryumova, 2010). In these articles the authors discuss the issues of small innovative businesses regarding all aspects of their operation and rely on comprehensive information of departmental accounting and the data of the expert survey of more than 210 directors of small innovative enterprises (105 chief executives in 2011 and 105 in 2012, respectively).

\section{Methodology}

The objective of the research is to analyze the efficiency of small innovative enterprises operation established by universities regarding their mediation between universities and producers as well as assessing their profitability and development prospects.

In this study the authors applied two methods to receive raw empirical information: Content analysis of the information in Innovative Activities of Russian Universities -the digests of the Ministry of Education and Science of the Russian Federation, summarizing the data for 2011 and 2012 (SMER, 2013), as well as the method of expert survey with personal interviews with directors of 210 small enterprises in 2013 and 105 experts in 2015, respectively. The survey was conducted uniformly in universities of 8 cities: Moscow, Saint Petersburg, Veliky Novgorod, Yaroslavl, Vladimir, Tver, Tula, Nizhny Novgorod, Saratov, Rostov-on-Don, Voronezh, Kazan, Yekaterinburg, Perm, Kemerovo, Novosibirsk, Krasnoyarsk, Tomsk.

The expert questionnaire for personal interviews includes the following indicators, represented in the operational schemes (Fig. 1-3). 


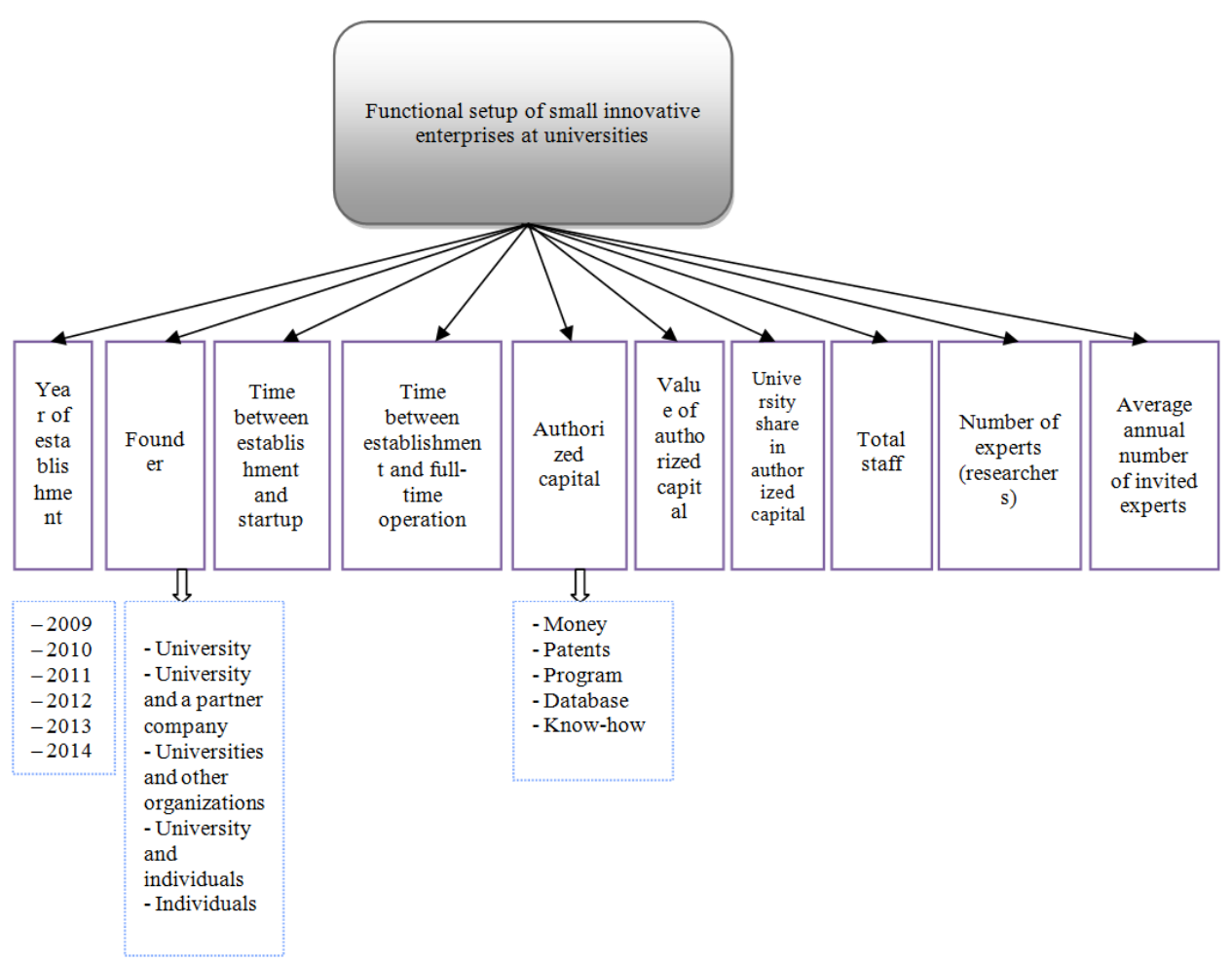

Fig. 1. Indicators of functional setup of small innovative enterprises at universities

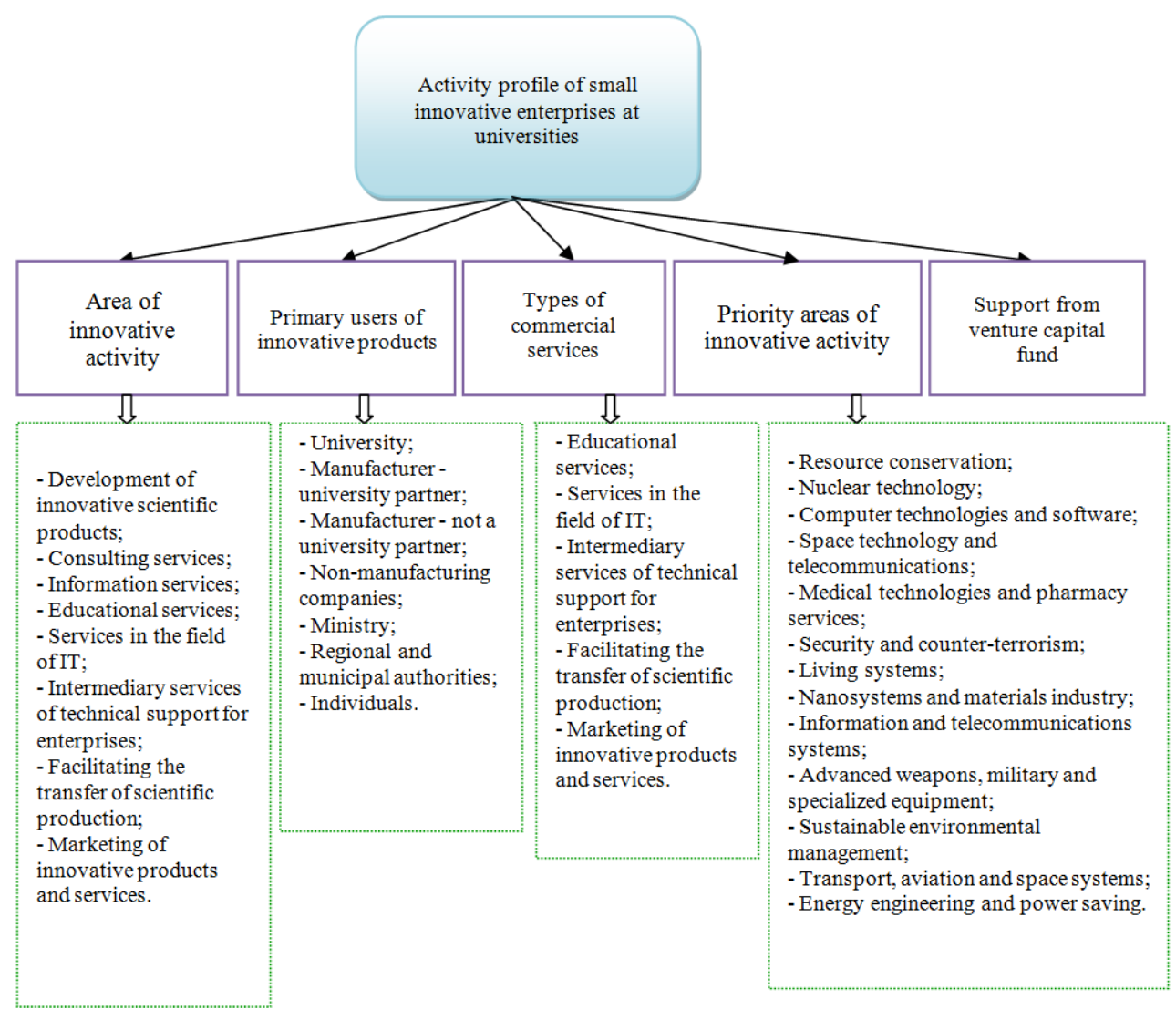

Fig. 2. Indicators of activity profile of small innovative enterprises at universities 


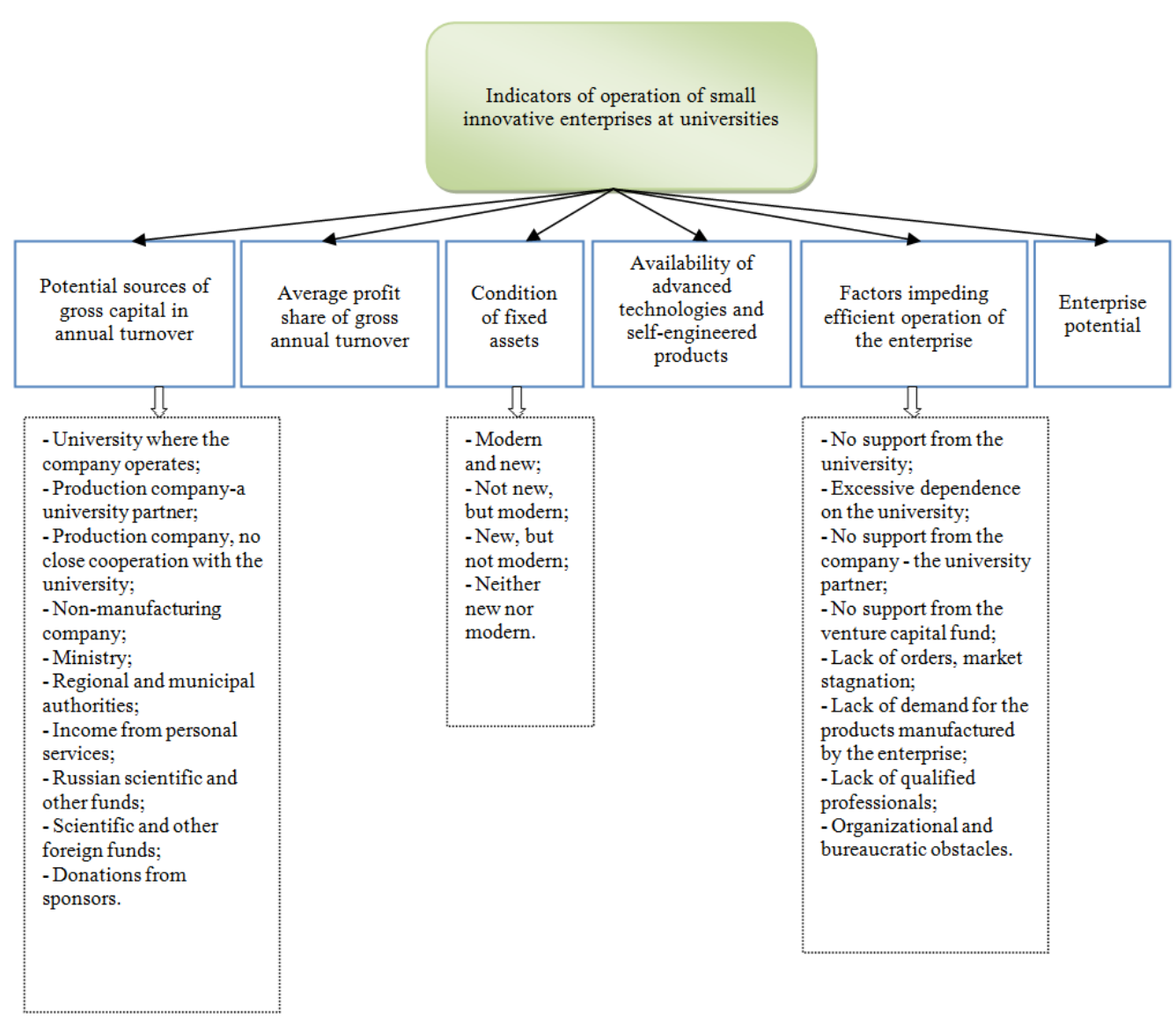

Fig. 3. Indicators of operation of small innovative enterprises at universities

\section{Results}

The majority- $96 \%$ of the existing small innovative enterprises at universities-were established in 20102012. By the beginning of 2012 there were 1048 small innovative enterprises in the electronic database of the Ministry of Education and Science of the Russian Federation. University management held to an opinion that small innovative enterprises, established by them, met the requirements imposed by the Government, regarding the classification of subsidiary small enterprises. However, the study showed that it is not the case for many small businesses. The reasons are as follows:

- A third of small enterprises could not provide the necessary amount of the authorized capital

- For a quarter of small enterprises the right to use intellectual property that did not belong to them (belonging to another person, legal entity, state) was included in the authorized capital to avoid paying the fee for a patent

In $90 \%$ of the universities the founders of small innovative enterprises believe that if the patent belongs to an employee of the university, then it also belongs to the university. In the $2000 \mathrm{~s}$, there was no legal guarantee for that, since in 1990s many employees of universities and research centers began registering the rights to inventions, utility models, pre-production prototypes in their name.

Parallel to the increase in small enterprises at universities, their average authorized capital decreased within a year after their establishment. For example, in December 2010 the average authorized capital of small enterprises, newly established by universities, accounted for RUB315.000 (USD10.500), but in March 2011 it was RUB270.000 (USD9.000). Unable to attract stable funding sources, small enterprises were rapidly "eating" their advance capital, especially in those $20 \%$ of small enterprise where $51-100 \%$ of the authorized capital belonged to the university. At the end of 2011 experts predicted that ongoing financial instability of university innovative enterprises would result in their number decreasing by two thirds. This forecast turned out to be incorrect; however, during the year after the establishment their number indeed decreased by $25 \%$.

According to an expert survey, by 2015 small enterprises working in the field of IT technologies became the most efficient. 
Table 1. Number and share of small innovative enterprises of universities in federal districts

\begin{tabular}{lcr}
\hline Federal district & Number & \multicolumn{1}{c}{$\%$} \\
\hline Central & 207 & 25.7 \\
Northwestern & 76 & 9.5 \\
Southern & 78 & 9.7 \\
North Caucasian & 26 & 3.2 \\
Volga & 181 & 22.5 \\
Ural & 54 & 6.7 \\
Siberian & 164 & 20.4 \\
Far Eastern & 18 & 2.3 \\
Total & 804 & 100.0 \\
\hline
\end{tabular}

Parallel to establishing small innovative enterprises, almost all major universities tried to participate in the implementation of major long-term research projects initiated by the government in 2010 (RFG Decree 218, 2010; RFG Decree 219, 2010; RFG Decree 220, 2010), so they did not have an economic interest to create their own business structure based only on university innovative enterprises. The development of small enterprises was accidental and their territorial distribution was uneven. As a result, at present $68.6 \%$ of small enterprises are centered in the universities of three federal districts: Central, Volga and Siberian (Table 1).

University innovative enterprises focus on the development of inventions and applied research. Among them, $40 \%$ are engaged in production (including installation, repair and maintenance), one third of the enterprises develop computer software and ITtechnology, 30\% are occupied with testing. Some are also engaged in consulting and information support. Only a few specialize in educational services and logistics (List 1).

$\begin{array}{cc}\text { List } & \text { 1-Areas } \\ \text { universities } & \text { activity of small enterprises at } \\ \text { Number } & \text { Percentage } \\ 693 & \text { 86.2-Development } \\ 622 & \text { 77.4-Research } \\ 335 & \text { 41.6-Manufacturing, installation, repair } \\ \text { and maintenance of machinery and } \\ \text { equipment } \\ 314 & \text { 39.0-Engineering } \\ 246 & \text { 30.6-Software, IT technology } \\ 235 & \text { 29.2-Test run, monitoring and diagnostics } \\ 130 & \text { 16.2-Consulting } \\ 111 & \text { 13.8-Information support } \\ 54 & \text { 6.7-Training } \\ 44 & \text { 5.5-Logistics, quality management, human } \\ & \text { resources }\end{array}$

Manufacturing accounts for two thirds of activity types performed by university innovative enterprises, whereas services make up for one third. Their products are used in 29 economic sectors, including 18 manufacturing branches. There is a substantial demand for the services university innovative enterprises provide in metal fabrication industries, power sector, information and computer services, health care, agriculture, construction, building maintenance, medical industry and transport (List 2).

$\begin{array}{ll}\text { List } & \text { 2-Application areas of university innovative } \\ \text { enterprises performance } \\ \text { Number } & \text { Percentage } \\ 118 & \text { 14.7-Metal fabrication industries } \\ 107 & \text { 13.3-Information and computer services } \\ 92 & \text { 11.4-Health care } \\ 82 & \text { 10.2-Power sector } \\ 72 & \text { 9.0-Agriculture } \\ 69 & \text { 8.6-Residential sector } \\ 65 & \text { 8.1-Construction, construction materials } \\ 65 & \text { 8.1-Medical industry } \\ 63 & \text { 7.8-Transport } \\ 50 & \text { 6.2-Science and scientific services } \\ 46 & \text { 5.7-Professional equipment } \\ 42 & \text { 5.2-Chemical industry } \\ 39 & \text { 4.8-Trade, tourism, welfare } \\ 31 & \text { 3.8-Food industry } \\ 31 & \text { 3.8-Training } \\ 27 & \text { 3.3-Telecommunications } \\ 27 & \text { 3.3-Hydrocarbon process industry } \\ 21 & \text { 2.6-Ecology, waste treatment } \\ 19 & \text { 2.4-Textile, clothing and footwear industry } \\ 19 & \text { 2.4-State and municipal management, economy } \\ 17 & \text { 2.1-Timber and woodworking industry } \\ 17 & \text { 2.1-Metallurgy } \\ 15 & \text { 1.9-Forestry } \\ 14 & \text { 1.7-Heavy equipment industry } \\ 14 & \text { 1.7-Oil and gas industry } \\ 11 & \text { 1.4-Fishery } \\ 11 & 1.4-\text { Microbiology } \\ 11 & 1.4-\text { Extraction and development of mineral } \\ & \quad \text { resources } \\ 11 & \text { 1.4-Coal industry } \\ & \end{array}$

At the initial stage of small innovative enterprises' development, one in two of them intended to operate in the field of computer technology, computer software development and telecommunication systems; one in four was going to work in transport, aviation and space systems, energy and energy efficiency. Till present university innovative enterprises demonstrate an avid interest in computer technology, programming and telecommunications systems. One in ten is interested in resource conservation, medical technologies and pharmacy services, nanosystems and materials. Nuclear technology, living systems, advanced weapons, military and specialized equipment, environmental management, power industry and power saving are not especially popular. Only $5 \%$ of small enterprises 
demonstrate interest in space technology and telecommunications, transport, aviation and space systems. Besides, they take practically no interest in security and counter-terrorism (Table 2 ).

The main customers of university innovative enterprises products are manufacturing companies, working in close collaboration with universities; companies which do not work together with universities on their scientific programs; universities themselves which manage small enterprises (List 3):

\section{List 3-Customers of university innovative enterprises products, $\%$}

50.0-Manufacturing companies, working in close collaboration with universities

48.1-Universities operating small enterprises

48.1-Manufacturing companies that do not work together with universities on their scientific programs

26.4-Individuals

20.8-Non-manufacturing companies

11.3-State and municipal authorities

7.5-Ministries

3.8-Other universities, Foundation for Assistance to Small Innovative Enterprises in Science and Technology

Starting efficiency of small innovative enterprises depends largely on the composition of the founders. Most successful is the start of those small businesses whose founders are university and a partner manufacturing company, working together on the implementation of the state scientific program (RFG Decree 218, 2010; RFG Decree 219, 2010). These enterprises started to work an average of one month after the establishment and switched to operating in the full mode 2.5 months after the establishment. For those small enterprises whose only founder is a university, the figures are 2.5 and 5 months, respectively; for those with a university and individuals as founders-3 and 5.5 months.

The composition of the authorized capital of small innovative enterprises is diversified. The authorized capital is formed of patents at $71.7 \%$ of small enterprises, software and electronic databases-56.6\%, property and equipment-52.8\%, cash- $44.3 \%$. Since 2010 the number of small enterprises whose authorized capital was formed by universities with the abovementioned contributions, except for patents, has increased, whereas the share of enterprises with patents in their authorized capital amounts for $70 \%$ (Table 3 ).

It is a somewhat different case with the share of contributions to the authorized capital of small enterprises from partner organizations. At the initial stage (2009) partner organizations made contributions to the authorized capital of most newly-established small innovative enterprises with money or patents. In 2012, however, one in two small enterprises received contributions into their authorized capital in form of cash, with no contributions in patents. Instead, there was an increase in contributed computer programs, databases, equipment and property (Table 4).

Table 2. Priority areas of applied research carried out by small enterprises, according to the year of establishment, $\%$

\begin{tabular}{|c|c|c|c|c|c|c|}
\hline \multirow[b]{2}{*}{ Priority area } & \multicolumn{6}{|c|}{ Year of establishment } \\
\hline & 2009 & 2010 & 2011 & 2012 & 2013 & 2014 \\
\hline Resource conservation & 12.5 & 21.9 & 23.3 & 27.8 & 30.1 & 34.6 \\
\hline Nuclear technology & 12.5 & 12.5 & 7.0 & 11.1 & 10.0 & 11.1 \\
\hline IT technology and software & 50.0 & 25.0 & 39.5 & 38.9 & 39.7 & 40.2 \\
\hline Space technology and telecommunications & 12.5 & 3.1 & 18.6 & 5.6 & 6.9 & 4.2 \\
\hline Medical technologies and pharmacy services & 25.0 & 15.6 & 20.9 & 27.8 & 24.1 & 27.5 \\
\hline Security and counter-terrorism & 12.5 & 3.1 & 11.6 & 0.0 & 4.4 & 5.3 \\
\hline Living systems & 12.5 & 6.3 & 9.3 & 11.1 & 8.8 & 10.3 \\
\hline Nanosystems and materials industry & 0.0 & 25.0 & 23.3 & 16.7 & 20.2 & 26.4 \\
\hline Telecommunication systems & 50.0 & 25.0 & 25.6 & 33.3 & 34.2 & 31.7 \\
\hline Advanced weapons, military and specialized equipment & 0.0 & 9.4 & 9.3 & 11.1 & 8.0 & 7.2 \\
\hline Sustainable environmental management & 12.5 & 21.9 & 20.9 & 11.1 & 12.2 & 14.9 \\
\hline Transport, aviation and space systems & 25.0 & 3.1 & 7.0 & 5.6 & 5.5 & 6.8 \\
\hline Energy and energy efficiency & 25.0 & 3.1 & 9.3 & 11.1 & 12.4 & 14.6 \\
\hline
\end{tabular}

Table 3. Types of university contributions to the authorized capital of small innovative enterprises, $\%$

\begin{tabular}{|c|c|c|c|c|c|c|}
\hline \multirow[b]{2}{*}{ Types of contributions } & \multicolumn{6}{|c|}{ Year of enterprise establishment } \\
\hline & 2009 & 2010 & 2011 & 2012 & 2013 & 2014 \\
\hline Cash & 25.0 & 28.1 & 55.8 & 50.0 & 51.2 & 55.8 \\
\hline Patents & 87.5 & 75.0 & 65.1 & 72.2 & 77.4 & 76.3 \\
\hline Software and electronic databases & 37.5 & 46.9 & 60.5 & 72.2 & 69.5 & 70.0 \\
\hline Property and equipment & 25.0 & 34.4 & 62.8 & 66.7 & 69.9 & 74.2 \\
\hline
\end{tabular}


Table 4. Types of partner organizations' contributions to the authorized capital of small innovative enterprises at universities, $\%$ Year of enterprise establishment

\begin{tabular}{|c|c|c|c|c|c|c|}
\hline \multirow[b]{2}{*}{ Types of contributions } & \\
\hline & 2009 & 2010 & 2011 & 2012 & 2013 & 2014 \\
\hline Cash & 75.0 & 31.3 & 23.3 & 44.4 & 53.5 & 64.1 \\
\hline Patents & 25.0 & 9.4 & 7.0 & 0.0 & 2.5 & 3.2 \\
\hline Software and electronic databases & 12.5 & 3.1 & 4.7 & 22.2 & 24.0 & 32.3 \\
\hline Property and equipment & 25.0 & 9.4 & 16.3 & 33.3 & 46.7 & 53.9 \\
\hline $\begin{array}{l}\text { Share of small innovative enterprises } \\
\text { with no contributions to their authorized } \\
\text { capital from partner organizations }\end{array}$ & 25.0 & 68.8 & 62.8 & 55.6 & 53.3 & 59.4 \\
\hline
\end{tabular}

As for the types of university contributions to the authorized capital of small operating enterprises, the situation is as follows: The bulk of cash contributions belongs individuals and universities; patents, software and databases in most cases belong to the university; property and equipment are mainly the property of the university and the partner organization (Fig. 4).

The data shown in Fig. 4 speak of the domineering role of universities in all parts of the authorized capital. Thus, it may be concluded that most of the universities have "controlling interest" in the small innovative enterprises they established.

Small enterprises established by universities independently or in partnership with other organizations or individuals are primarily engaged in the development of scientific products for companies providing services in the field of IT. Transfer of scientific products into production is carried out mainly by small enterprises, established by universities only or universities, collaborating with partner manufacturing companies.

The lack of adequate base capital is a serious obstacle to efficient operation of small innovative enterprises at universities. At the initial development stage (20092012), 70\% of small enterprises had authorized capital of not more than RUB300,000 (USD10,000), of which 50\% of the authorized capital was in most cases owned by the university. Every second company had the authorized capital of not more than RUB100,000 (Fig. 5).

The initial stage is the longest for those small enterprises that develop scientific innovations for other companies or provide intermediary services of maintenance for manufacturing enterprises; while the shortest initial state was registered at the enterprises, providing consulting services on innovations (Table 5).

The average number of full-time employees of small enterprises of universities is 3 people, their average age is 36.4. The average number of employees working parttime is 5-6 people, including teachers-2-3 people, postgraduates (doctoral students)-2 people, students (bachelors, masters)-3, researchers-2-3 people.

Compared to these figures, small university enterprises, collaborating with manufacturing companies and research organizations on the implementation of the state scientific program, seem to be quite prosperous:
The average number of employees is 22 people, including specialists working in development (researchers, engineers)-14 people. In addition, these small businesses invite an average of 12 people to work on a part-time basis annually. These small enterprises are able to show such results due to the stable state budget financing of the research program done by universities in cooperation with manufacturing enterprises and scientific organizations.

According to the monitoring results, at present $53.6 \%$ of small university enterprises manufacture some kind of products. In 2014 the total volume of created products and services provided by small university enterprises amounted to RUB129.5 $\mathrm{mln}$ (USD4.3 $\mathrm{mln}$ ), that is RUB2.7 mln (USD90,000) per one enterprise. The volume of budget funds, transferred by universities to the incorporated small enterprises amounted to RUB420.4 mln (USD14 mln.), i.e., one third of the total annual turnover of small university enterprises. The total volume of goods and services per staff member is RUB656.700 (USD18.200 according to the average exchange rate in 2014).

The results of the expert survey enabled to design the structure of the total annual turnover of small innovative enterprises at universities (Fig. 6).

The data in Fig. 6 show that almost half of the annual turnover (43\%) of small enterprises was provided by the universities that incorporated these entities and the same number $(44 \%)$ by manufacturing companies. Russian scientific funds provide $5 \%$ of the annual turnover of small enterprises and other sources account for the remaining $8 \%$.

At the initial state of small innovative enterprises setting-up (2009), one in two enterprises was unprofitable. In $2014,23.5 \%$ of small enterprises did not get any profit. In general, profits of small enterprises vary in the range of $6-11 \%$ of the annual turnover. Nowadays profitable small enterprises are mainly those, participating in the implementation of the state scientific program. The average profit of $76.4 \%$ of these companies accounts for $10 \%$ of the gross annual turnover.

Small university enterprises are profitable for most activity types (Fig. 7). 


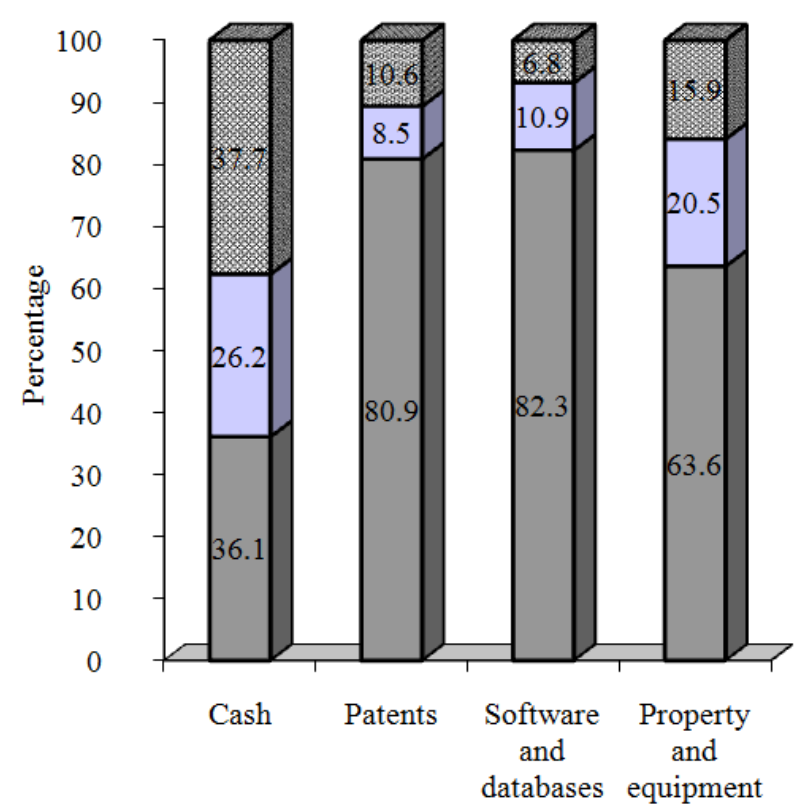

Owned by individuals

Oowned by partner enterprises

Downed by university

Fig. 4. Composition of the authorized capital of small enterprises by the contribution type from universities, partner enterprises and individuals, $\%$

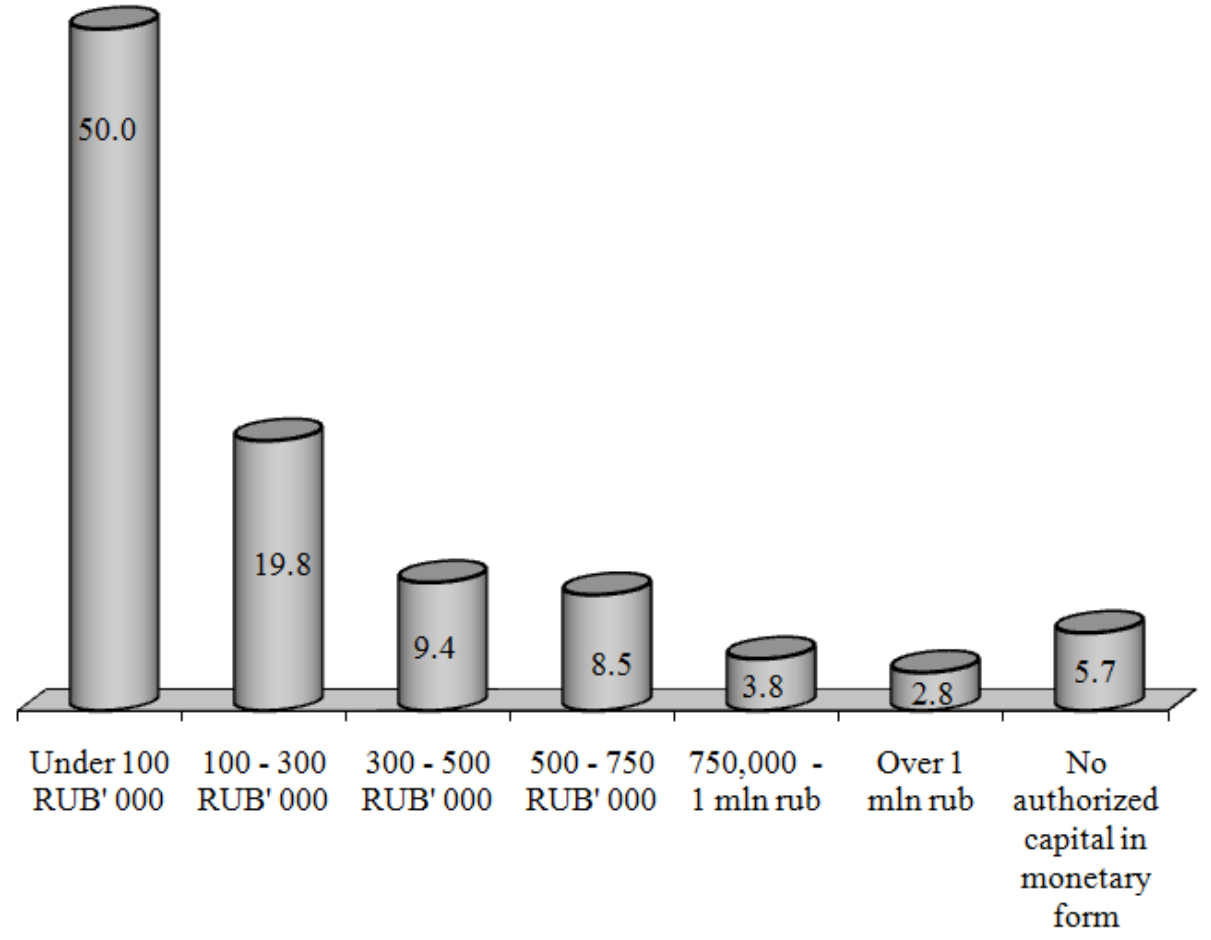

Fig. 5. Distribution of small innovative enterprises of universities according to the value of the authorized capital, $\%$

The cost of fixed assets of small university enterprises is RUB149.6 mln (USD5 mln); per one small enterprise-RUB0.5 mln (USD16.700). On the average, $80.4 \%$ of fixed assets (RUB120.2 $\mathrm{mln}$, or USD4 mln total value) are made up of machinery and equipment. The total amount of equipment per one small enterprise is 7 units, where in-house equipment is 6 units. Small enterprises rent $28 \%$ of machinery and equipment. In scientific areas, the mean number of machinery and equipment per enterprise varies from 5 to 9 units, including in-house equipment-from 4 to 8 units (Table 6). 


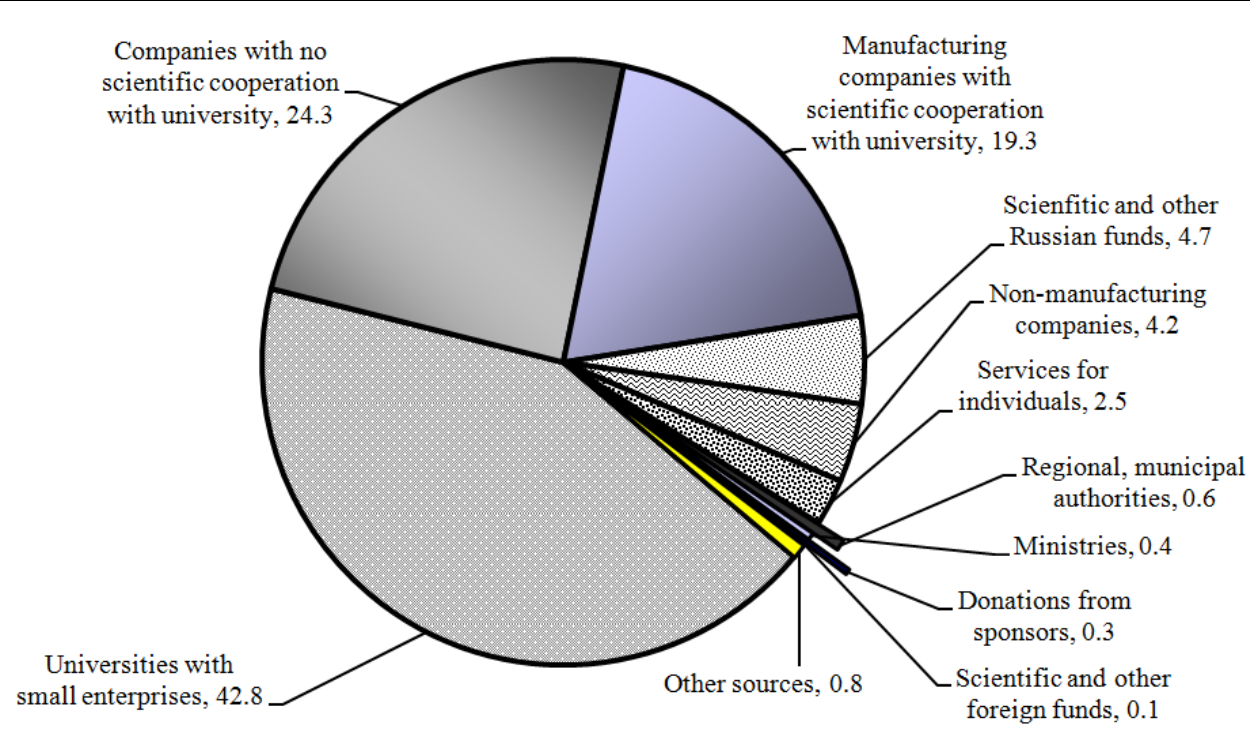

Fig. 6. Normalized share of different funding sources in the annual turnover of the small innovative enterprises of universities, \%
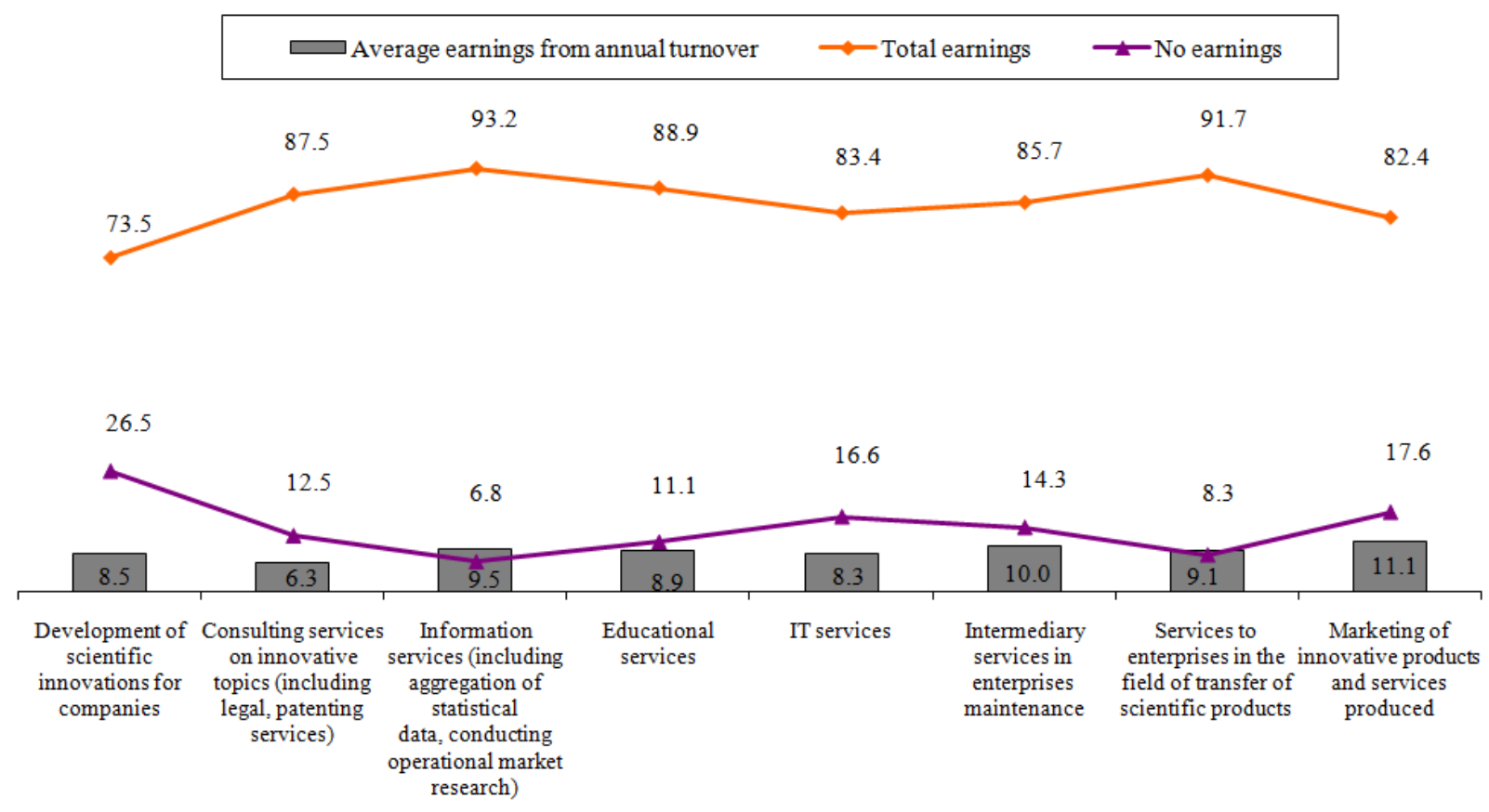

Fig. 7. The ratio of average earnings to the annual turnover of small enterprises, depending on the type of work activity, $\%$

The average deterioration rate of fixed assets of small university enterprises is $25 \%$, which proves the situation is fairly positive. In fact, the spread of these figures is quite large. Modern and new fixed assets are owned by $51 \%$ of small businesses, the deterioration rate of their assets is $15 \%$. For another $34 \%$ the deterioration rate is $30 \%$. The enterprises renting fixed assets $(15 \%)$ have the depreciation rate of $60-65 \%$.

Small enterprises whose main activity is providing educational services demonstrate a higher than the average depreciation rate of fixed assets-30\%. It goes no lower than average (25\%) for small enterprises, developing scientific products for manufacturing companies and providing consulting services. The low depreciation rate of fixed assets $(15 \%)$ is shown by small enterprises that provide information and intermediary services of company maintenance.

The average area occupied by a small enterprise is $53.3 \mathrm{~m}^{2}$, including their own area of $33.4 \mathrm{~m}^{2}$. University premises are rented by $47.7 \%$ of small enterprises, premises owned by other organizations- $76.2 \%$. However, this is only a third of the total area occupied by small enterprises. $33.8 \%$ of small enterprises have difficulties with renting premises. 


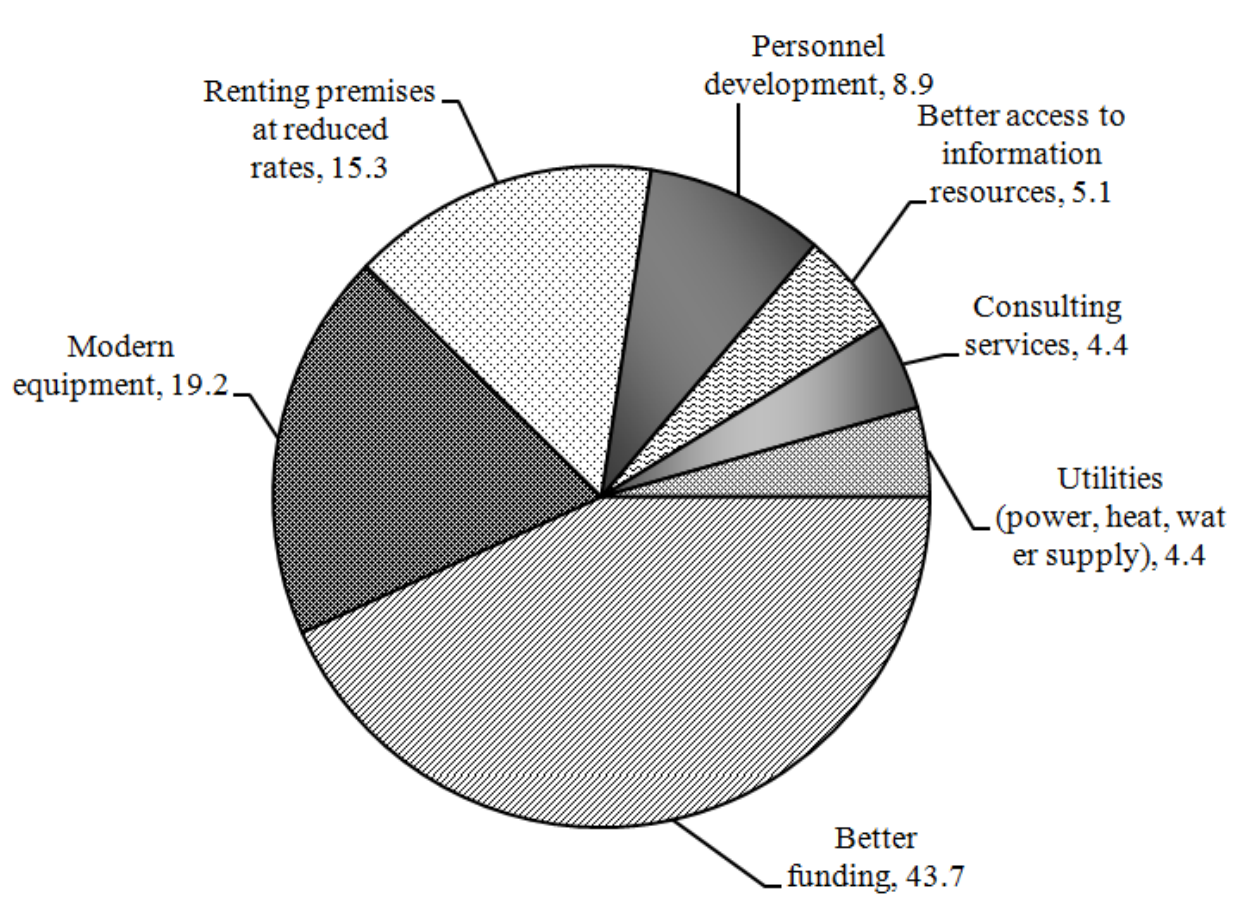

Fig. 8. Factors that can improve the company’s performance, according to the directors of small enterprises, $\%$

Table 5. Areas of activity of small innovative enterprises at universities according to their starting characteristics

\begin{tabular}{|c|c|c|c|}
\hline Main area of activity & $\begin{array}{l}\text { Months between } \\
\text { establishment and } \\
\text { starting the operation }\end{array}$ & $\begin{array}{l}\text { Months between } \\
\text { establishment and } \\
\text { full operation }\end{array}$ & $\begin{array}{l}\text { University share in the } \\
\text { authorized capital of the } \\
\text { established small enterprise, \% }\end{array}$ \\
\hline $\begin{array}{l}\text { Development of scientific } \\
\text { innovations for companies }\end{array}$ & 3.0 & 5.5 & 45 \\
\hline $\begin{array}{l}\text { Consulting services on innovative topics } \\
\text { (including legal, patenting services) }\end{array}$ & 1.5 & 2.0 & 55 \\
\hline $\begin{array}{l}\text { Information services } \\
\text { (including aggregation of statistical data, } \\
\text { conducting operational market research) }\end{array}$ & 1.5 & 3.5 & 50 \\
\hline Educational services & 2.0 & 4.0 & 50 \\
\hline IT services & 2.0 & 3.5 & 50 \\
\hline $\begin{array}{l}\text { Intermediary services in } \\
\text { enterprises maintenance }\end{array}$ & 2.5 & 6.5 & 50 \\
\hline $\begin{array}{l}\text { Services to enterprises in the } \\
\text { field of transfer of scientific products }\end{array}$ & 2.0 & 4.5 & 55 \\
\hline $\begin{array}{l}\text { Marketing of innovative } \\
\text { products and services produced }\end{array}$ & 2.0 & 5.5 & 50 \\
\hline
\end{tabular}

Table 6. Volume of fixed assets of small enterprises

\begin{tabular}{|c|c|c|c|}
\hline \multirow[b]{2}{*}{ Area of priority } & \multirow[b]{2}{*}{$\begin{array}{l}\text { Fixed assets, } \\
\text { RUB '000 }\end{array}$} & \multicolumn{2}{|c|}{ Equipment, units } \\
\hline & & Total & Including in-house \\
\hline Security and counter-terrorism & $249.3(\$ 8.3)$ & 9.0 & 8.0 \\
\hline Living systems & $380.2(\$ 12.9)$ & 6.0 & 5.0 \\
\hline Nanosystems and materials industry & $771.8(\$ 25.7)$ & 8.0 & 6.0 \\
\hline Telecommunication systems & $255.0(\$ 8.5)$ & 8.0 & 6.0 \\
\hline Sustainable environmental management & $999.2(\$ 33.3)$ & 6.0 & 6.0 \\
\hline Transport, aviation and space systems & $205.5(\$ 6.9)$ & 7.0 & 7.0 \\
\hline Resource conservation and nuclear technology & $635.6(\$ 21.2)$ & 9.0 & 7.0 \\
\hline Other & $413.2(\$ 13.8)$ & 5.0 & 5.0 \\
\hline Average for small university enterprises & $476.4(\$ 15.9)$ & 7.2 & 6.1 \\
\hline
\end{tabular}


There is an average of 2.3 research and development works carried out in collaboration with university per one small enterprise. The average volume of these works in terms of value amounts for RUB1.8 $\mathrm{mln}$ (USD60,000). In 2014 the average volume of innovations carried out by small university enterprises per contract did not exceed RUB770,000 (USD25,000) in terms of value.

The average amount of patents received by small enterprises by the end of 2014 is 1.5 , protectable research and development deliverables-2 items.

Priority area products and technologies are relatively easy introduced into production by those small enterprises that work in the field of advanced weapons, military and special equipment, nanosystems and materials industry. Commercial development of their products is challenging for enterprises working in sustainable environmental management, energy efficiency and resource conservation, transportation, aviation and space systems; living systems, information and telecommunication systems, medical technology and pharmaceutical industry.

According to the survey of the directors of small enterprises, even nowadays bureaucratic and organizational hurdles remain one of the main obstacles to successful operation of the enterprise, regardless of the year of establishment. The lack of orders and stagnation of the market represented serious challenges for the development of an enterprise at the initial stage, but enterprises founded in the last 2-3 years choose their specialization more elaborately and, therefore, can respond more adequately to the needs of the market.

Despite the difficulties, $79 \%$ of the executives surveyed consider the potential of their enterprises as high. Most directors (85-95\%) who expressed confidence in the prospects of their enterprises were the executives of small companies assisting manufacturing companies with the transfer of scientific products, those providing intermediary services of maintenance, consulting services (including legal, patenting services) and IT services.

Directors of enterprises specializing in transport, aviation and space systems, power industry and power saving, space technology and telecommunications, security and counter-terrorism are most optimistic about the prospects of their enterprise; the lowest level of confidence is shown by executives of enterprises working in living systems, resource conservation, medical technology and pharmaceutical industry, sustainable environmental management.

Executives' opinion strongly depends on the state of the fixed assets. The vast majority (91\%) of directors whose enterprises have new and modern fixed assets and their deterioration rate is no more than $20 \%$ consider their enterprise's activity as promising. For enterprises with neither new nor modern fixed assets and the deterioration rate of no less than $45 \%$, there are only $29 \%$ executives with positive opinion. The enterprise's activity is regarded as prospective among $90 \%$ of directors in case of new technologies, developments and their successful application in production; for enterprises with no such technologies or developments or the lack of demand, the proportion of optimistic executives is only $25 \%$.

According to the directors of small enterprises, the factors that can improve the company's performance primarily deal with better funding, modern equipment, renting premises at reduced rates and personnel development (Fig. 8).

\section{Discussion}

The findings speak of the successful extensive development of small innovative enterprises of universities. Both at the early stage and till present day the main customers of small innovative enterprises are universities and companies either cooperating or not in the implementation of the state scientific program, initiated by the Government of the Russia (RFG Decree 218, 2010; RFG Decree 219, 2010). Municipal authorities cooperated with small enterprises only in 2010 and 2011, but since 2012 there was a significant decrease in the investment activity of the authorities. Small enterprises, established in 2012, had practically no interaction with the authorities or the Ministries, the situation remaining unchanged till present day.

Survey findings indicate that not only the number of small enterprises was growing quite rapidly, but they began operation in full mode in a relatively short period of time, especially those involved in the implementation of the state scientific program and cooperating with manufacturing companies and research organizations: On an average of 2.5 months after their establishment, these small innovative enterprises began work and became fully operational on an average of 5 months.

The profitability of small enterprises in most priority areas is quite low; for all enterprises the payroll is higher than $40 \%$. For such priority areas as security and counter-terrorism, sustainable environmental management the payroll "eats" no less than $80 \%$ of the turnover, thus impeding the development of the fixed assets of the enterprise. In this respect, the worst situation is for enterprises operating in the following five areas: Computer technology and software, medical technology and pharmaceutical industry, space technology and telecommunications, power industry and power saving; advanced weapons, military and special equipment. Their total turnover is "eaten" by the payroll.

Losses of small enterprises in $50 \%$ of cases are covered by the university, which often corresponds to its share in the authorized capital of the small innovative enterprises established by it. In contrast, partner 
enterprises rarely do that-one in ten cases, only when they cover losses together with the university. In every second case the losses are covered by individuals with help of a loan.

The average cost of $1 \mathrm{~m}^{2}$ rented by small enterprises amounts for RUB1.400 a month (USD44, or about USD500 per year), including the premises rented from university-RUB900 (USD30, or USD360 per year), from other owners-RUB1.700 per month (USD57, or USD680 per year). This price is rather high, especially considering that the majority of small enterprises operate outside Moscow or St. Petersburg-in the regional cities where rental costs are considerably lower. For small enterprises this rental cost means losing money, while landlords abuse their monopoly or launder money.

The application of their technologies and inventions in production is the easiest for small enterprises providing services to companies in the field of transfer of scientific products, intermediary services in enterprises maintenance and information services. It turns out to the hardest for the enterprises, developing scientific products for manufacturing companies, those providing educational services or services in the field of IT, consulting services in innovative areas.

Most small innovative enterprises, whose products are ordered by their own university or a manufacturing company that works together with the university on the state scientific program, are able to apply their technologies and developments in the industry, while many others may experience serious difficulties.

Interviewed executives of small innovative enterprises name venture capital funds to be ineffective. At the initial state of small innovative enterprises development (2009), every second of them did not need the support of a venture capital fund, but in 2010 the proportion of these enterprises decreased to $16 \%$, in 2011 to $7 \%$. As for small enterprises, established in $2012,100 \%$ of them stated they need the support of the venture capital fund. Today, the fund supports only $3.8 \%$ of small university enterprises, whereas $10.4 \%$ require an emergency aid from the regional venture fund.

In general, at present day only $13.2 \%$ of small innovative enterprises do not need the help from the venture fund. It is possible that the lack of interest of venture capital funds in small university enterprises comes as a result of the university's monopoly when forming business policies of an enterprise.

The lack of support from a venture capital fund and the lack of orders for innovative products are the main difficulties for small enterprises. As for the first reason, it mainly concerns small innovative enterprises providing information, intermediary services, assisting manufacturing enterprises in the transfer of scientific products; the second one-those carrying out research on innovative products development, providing consulting services on innovations and educational services.
The shortage of professionals primarily concerns small innovative enterprises working in the following areas: Nuclear technology, nanosystems and materials industry, computer technologies and software, resource conservation, living systems.

Many executives of small innovative enterprises do not believe in the viability of their companies for two reasons: Shortage of qualified specialists and the lack of support from the venture capital fund. Among other obstacles they name bureaucracy and inadequate management, the enterprise's over-reliance on the university and insufficient help the university provides.

\section{Conclusion}

We may see an uneven distribution of small innovative enterprises of universities. Currently, $70 \%$ of small enterprises are concentrated in the universities in three federal districts out of nine, these are Central, Volga and Siberian Federal Districts.

According to the analysis of the official statistics and the expert survey, we can conclude about a steady decline in the authorized capital of small university enterprises, apparently due to their reluctance to risk their own capital.

There are few small university enterprises in the market of innovative products, most enterprises focus on research programs carried out by the university where they were established.

Regardless of the year of establishment, development of innovative products for manufacturing companies remains the main activity for small enterprises. There is a growing proportion of small enterprises that assist manufacturing companies in the marketing of innovative products and services produced. As for small innovative enterprises of universities participating in the state scientific program together with manufacturing companies and research organizations, the main customers of their products are manufacturing companies, closely cooperating with the university as well as universities themselves, where these small enterprises operate.

Two thirds of small enterprises work in industry, one third provides various types of services. Today the products of small university enterprises are used in 29 sectors, among which $60 \%$ in manufacturing industries.

Interaction of small enterprises with regional authorities and with ministries, active at an early stage of development, by today has been "nullified"; however, more individuals are cooperating with small enterprises.

The most successful start-up is of those small enterprises, where the founders are the university and a partner company involved in the implementation of the state scientific program. The average share of universities participating in the state scientific program, in the authorized capital of small enterprises amounts for 
$50 \%$. In general, the major share of cash contributions to the authorized fund of small enterprises accrues to individuals and universities; patents, software and databases brought to the authorized capital are mostly owned by the university; machinery and equipment-by the university and a partner manufacturing company. In most cases, universities have a controlling stake in the small innovative enterprises.

The lack of sufficient base capital is an important issue for small innovative enterprises; among them, 70\% have an authorized capital of not more than RUB 300,000 (USD 10,000).

The average number of employees at small university enterprises is 3 people, the number of external parttimers 6 people. According to this criterion, many of these small-scale enterprises can be compared with sole proprietorship. The situation is different for small university enterprises cooperating with manufacturing companies and research organizations and involved in the implementation of the state scientific program. Here, the average number of personnel is 22 people, among which professionals working in development (researchers of engineers) 14 people.

The potential of small university enterprises can be considered as low today. In 2014 not more than 55\% of small enterprises released some products, the total cost of these being not more than RUB1.3 bln (USD44 mln), i.e., the average productivity per small enterprise was RUB2.7 mln of the annual turnover (USD90,000). The money of the state budget constituted a third of this sum. Given the high cost of scientific production, it is not surprising that half of small enterprises used nearly all its funds for payroll, thus carrying a large tax burden. The profitability of small enterprises in most priority areas of science is low, there is not an area where the payroll is less than 40\%; and for areas such as security and counter-terrorism, sustainable environmental management the payroll "consumes" $80 \%$ of the annual turnover, hindering the development of fixed assets of the enterprise.

Over $80 \%$ of the fixed assets of small enterprises accrue to machinery and equipment. It suffices for intellectual activities that basically mean working at a computer, but if the enterprise's activities involve design, modeling, creating prototypes, testing, such assets are obviously insufficient and the enterprise has to rent machinery, equipment, testing facilities. The fixed assets of small innovative enterprises working on the state scientific program together with manufacturing companies and research organizations are much better than those of most small university enterprises, not involved in the implementation of the state scientific program. Among them, at least $80 \%$ have modern-or new for the majority-machinery and equipment, the depreciation rate of fixed assets for such small enterprises does not exceed $25 \%$.
Most small innovative enterprises, whose products are ordered by their own university or manufacturing company, cooperating with the university in the state scientific programs, are able to apply their technologies and developments in the industry.

According to the executives of small enterprises, bureaucracy and inadequate management still remain main obstacles to successful operation of the company. It is also impeded by the shortage of specialists and the lack of support from the venture capital fund, although today at least $85 \%$ of small university enterprises need such assistance.

Considering the prospects, the situation may be called favorable only for small innovative enterprises at universities that work together with manufacturing companies and research organizations on the state scientific program.

\section{Acknowledgement}

This study was carried out as a part of scientific program of the Center for Sociological Research, approved by the Ministry of Education and Science of Russia in 2016 (state assignment 28.49.2016/HM).

\section{Author's Contributions}

Franz Edmundovich Sheregi: Developed the plan of the research and carried out the study, data collection of the study sample, analysis and writing of the manuscript.

Alexey Valentinovich Ridiger: Participated in the results analysis, contributed to the drafting of the article and provided critical reviewing for significant intellectual content.

\section{Ethics}

The authors have no conflicts of interest in the development of the research and publication of this article.

\section{References}

Alexandrin, Y.N., 2011. Innovacionnaja ekonomika i institucionalnaja sreda malogo predprinimatelstva. Russia World Today, 4: 101-113.

Arkhipov, Y.A., 2010. Gosudarstvennaja podderzhka malyh innovacionnyh predprijatij $\mathrm{i}$ perspektivy ih razvitija. Microeconomics, 1: 56-60.

Avilova, V.V. and E.V. Khvorova, 2011. Upravlenie innovacionnym predprinimatelstvom V sovremennyh uslovijah.

Basareva, V.G., 2014. Gosudarstvennoe upravlenie malym biznesom: Ot zadach do realizacii. ECO, 12: 126-136.

Bryalina, G.I., 2014. Innovacionnye vozmozhnosti rossijskogo malogo biznesa. Economics, 1: 85-96. 
Chepurenko, A.Y., 2009. Malyj biznes v rynochnoj srede. Small business in the market environment. Publishing House of International University in Moscow.

Chuka, L. and Z.Y. Panina, 2014. Novye vozmozhnosti finansirovanija malogo biznesa. Money Credit, 5: 31-33.

RFG Decree 218, 2010. Decree of the Government of the Russian Federation No 218. On Measures of State Support for the Development of Cooperation between Russian Higher Education Institutions and Organizations Implementing Comprehensive Projects on Creation of High-tech Production.

RFG Decree 219, 2010. Decree of the government of the Russian Federation No 219. On the state support of innovation infrastructure development in Federal Educational Institutions of Higher Education.

RFG Decree 220, 2010. Decree of the government of the Russian Federation No 220. On measures to attract the leading scientists to Russian Institutions of Higher Education.

RFG Decree 146, 2011. Decree of the government of the Russian Federation No. 146. On the register of notifications of the creation of economic companies founded by budget-supported scientific Institutions and Institutions of Higher Professional Education and the Procedure of Its Transfer to Control Bodies in Charge of the Payment of Insurance Contributions.

Fiyaksel, E.A. and N.N. Butryumova, 2010. Vzaimodejstvie malyh innovacionnyh predprijatij rannih stadij razvitija i elementov infrastruktury regionalnoj innovacionnoj sistemy. Regionology.

Grasmick, K.I. and A.V. Mezenin, 2013. Mezhfirmennye svjazi i ih rol $\mathrm{v}$ razvitii malyh innovacionnyh predprijatij. Economics, 5: 74-83.

Kantserov, R.A. and K.T. Gediev, 2012. Metody ocenki potenciala malyh predprijatij. National Interests: Priorities Security, 10: 18-23.
Lapusta, M.G. and Y.L. Starostin, 1998. Maloe predprinimatelstvo. Moscow.

SMER, 2013. Maloe i srednee predprinimatelstvo v Rossii. Statistical Yearbook, SMER.

SBR, 2005. Maloe predprinimatelstvo V Rossii. Statistical Digest, SBR.

MES Order 1404, 2011. On implementation of decree of the government of the Russian Federation.

Osipov, G.V., M.N. Strikhanov and F.E. Sheregi, 2014. Vzaimosvjaz nauki i proizvodstva. Sociologicheskij analiz .Center for Social Forecasting and Marketing. Moscow.

RFL 127-FZ, 1996. Russian federal law No. 127-FZ. On Science and Government Policy in Science and Technology.

RFL 41-FZ, 1996. Russian federal law No. 41-FZ. On Production Cooperatives.

Sgroi, F., A.M. Di Trapani, R. Testa and S. Tudisca, 2014. Strategy to increase the farm competitiveness. Am. J. Agric. Biol. Sci., 9: 394-400. DOI: 10.3844/ajabssp.2014.394.400.

Sheregi, F.E., M.N. Strikhanov and V.I. Savinkov, 2012. Perspektivy vzaimodejstvija proizvodstva i nauki [Prospects for interaction of industry and science]. Universities and Research Institutes.

Sheregi, F.E. and G.A. Klyucharev, 2013. Partnerskoe vzaimodejstvie kompanij, vuzov i nauchnoissledovatelskih organizacij dlja realizacii nauchnyh programm i innovacionnogo proizvodstva. Center for Social Forecasting and Marketing.

Tarasenko, A. 2011. Problemy malogo innovacionnogo biznesa. Economist, 10: 57-62.

Zinov, V.G. and S.A. Tsyganov, 2009. Vzaimodejstvie malogo predpriyatiya i NII $\mathrm{v}$ innovacionnyh proektakh. Innovations.

Zubova, L.G., O.N. Andreeva and O.A. Antropova, 2013. Maloe innovacionnoe predprinimatelstvo $\mathrm{V}$ vedushhih rossijskih universitetah: Sostojanie i faktory razlichija. Innovations, 6: 54-63. 